\title{
Radiocarbon
}

1995

\section{RADIOCARBON AGE OFFSETS IN DIFFERENT-SIZED CARBONATE COMPONENTS OF DEEP-SEA SEDIMENTS}

\author{
JOHN THOMSON, ${ }^{1}$ G. T. COOK, ${ }^{2}$ ROBERT ANDERSON, ${ }^{2}$ A. B. MACKENZIE, ${ }^{2}$ \\ D. D. HARKNESS ${ }^{3}$ and I. N. McCAVE
}

\begin{abstract}
We compared accelerator mass spectrometry (AMS) ${ }^{14} \mathrm{C}$ ages of large $(>150 \mu \mathrm{m}$ ) pelagic foraminifera with radiometric bulk carbonate ${ }^{14} \mathrm{C}$ ages in two northeastern Atlantic cores. The foraminiferal ages are consistently older than those of the bulk sediment (by $+0.76 \mathrm{ka}$ in Core 11881 and by $+1.1 \mathrm{ka}$ in Core 11886), whereas corresponding fine $(<5 \mu \mathrm{m})$ fraction ages are similar to those of the bulk sediment carbonate. We calculated near-identical sediment accumulation rates from both the foraminiferal and bulk sediment age/depth relations $\left(3.0 \mathrm{~cm} \mathrm{ka}^{-1}\right.$ in Core 11881 and $5.9 \mathrm{~cm} \mathrm{ka}^{-1}$ in Core 11886$)$. Consideration of various factors that might produce such offsets leads us to believe that they are not artifacts, but were most probably caused by differential bioturbation of the different size-fractions in the sediment surface mixed layer. The importance of this finding is that many paleoceanographic records, such as the oxygen isotope record, also derive from analyses of large foraminifera, so that these records must be offset in time from the bulk of the sediments that they characterize.
\end{abstract}

\section{INTRODUCTION}

Recent advances in ${ }^{14} \mathrm{C}$ analysis provide a powerful new technique for investigating the accumulation process in carbonate sediments and the surficial processing of sediment by biological activity before burial. Until the mid-1980s, ${ }^{14} \mathrm{C}$ dating was performed by radiometric analysis of the carbon derived from sediment carbonate. This typically requires a minimum of $10 \mathrm{~g} \mathrm{CaCO}_{3}$, but with the development of accelerator mass spectrometry (AMS), it became possible to analyze much smaller samples with similar precision ( $c a .1 \mathrm{mg} \mathrm{C}$ or $10 \mathrm{mg} \mathrm{CaCO}_{3}$ ). Therefore, the latter technique rapidly became the method of choice for dating recent sediments because it consumed much less of the limited material available in a deep-sea core. In particular, the analysis of hand-picked foraminifera has become popular because their large shells (in the size range 63 to $400 \mu \mathrm{m}$ ) make them less liable to current redistribution (e.g., Duplessy et al. 1986; Broecker et al. 1988a; Jansen and Veum 1990). The contrasting ages of coexisting pelagic (surface-living) and benthic (bottom-dwelling) foraminifera gives an estimate of the ${ }^{14} \mathrm{C}$ age differences between surface and deep waters at different times and provides information for carbon cycle and ocean circulation studies (Broecker $e$ t al. 1988b). We describe here a comparison of AMS ages of large pelagic foraminifera with those of the total-sediment carbonate; such comparisons have been made in relatively few previous studies (Jones et al. 1989; Paull et al. 1991).

In the past 15 years, great advances have been made in the quantification of surficial sediment bioturbation intensity and the depth over which it operates. Such investigations have mainly involved the use of relatively short-lived natural radionuclides such as ${ }^{210} \mathrm{~Pb}_{\text {excess }},{ }^{32} \mathrm{Si}$ and ${ }^{234} \mathrm{Th}_{\text {excess }}$, (e.g., Nozaki et al. 1977; DeMaster and Cochran 1982; Aller and DeMaster 1984) or nuclear device fallout nuclides such as ${ }^{239,240} \mathrm{Pu}$ and ${ }^{137} \mathrm{Cs}$ (e.g., Cochran 1985; Smith et al. 1986). Currently, most bio-

\footnotetext{
${ }^{1}$ Institute of Oceanographic Sciences Deacon Laboratory, Brook Road, Wormley, Godalming, Surrey, GU8 5UB, England ${ }^{2}$ Scottish Universities Research and Reactor Centre, Scottish Enterprise Technology Park, East Kilbride, G75 0QF, Scotland ${ }^{3}$ NERC Radiocarbon Laboratory, Scottish Enterprise Technology Park, East Kilbride, G75 0QF, Scotland

${ }^{4}$ Department of Earth Sciences, University of Cambridge, Downing Street, Cambridge, CB2 3EQ, England
} 
turbation models used in the treatment of radionuclide data assume that all components are equally well mixed at a constant intensity over a fixed depth (e.g., Bard et al. 1987). Several theoretical (Boudreau 1986a,b) and biological (Wheatcroft et al. 1990; Smith 1992) considerations of the mixing process have indicated that there are good reasons to expect that biological mixing should 1) be sensitive to particle size, and 2) fall off in intensity with increasing depth in the sediments. There is strong evidence that the bioturbation intensities derived from radionuclide data are tracer-dependent; this has been ascribed to more active bioturbation of freshly deposited material (Smith et al. 1993). Experimental particle size/tracer work also demonstrates a significant decrease in biological diffusivity with increasing particle size (Wheatcroft 1992). From a sedimentological or stratigraphic standpoint, the importance of bioturbation is that it blurs the potential resolution contained in the sediment record (Schiffelbein 1984, 1985). Another quite different complication of bioturbation for sedimentology studies is that differential size-mixing would create apparent lead-lag offsets and differential peak-amplitude reductions for different-sized sediment components. Ruddiman et al. (1980) undertook a specific sedimentological study designed to test for size and shape dependency in the mixing of deep-sea sediments, and studied the distributions of ash and tektite layers now observed at depth in cores, assuming that they were originally emplaced as single-event layers. The authors concluded qualitatively that bioturbative mixing was neither size- nor shape-dependent in size ranges between 11 and $500 \mu \mathrm{m}$. However, subsequent statistical analysis of the same data by Wheatcroft and Jumars (1987) led to the conclusion that the mixing intensity did, in fact, increase slightly with decreasing particle diameter. Sanderson (1985) and McCave (1988) presented evidence that large (non-ingestible) particles of gravel size (at least 2-100 $\mathrm{mm}$ ) are actually moved upward by bioturbation, rather than being buried. It is not known at what particle diameter the latter process begins to operate, but some mechanism is necessary to avoid the burial of manganese nodules that accumulate orders of magnitude more slowly than the sediments on which they rest. McCave (1988) suggested that particles larger than the body diameters of the bioturbating organisms are liable to be pumped upward, rather than mixed diffusively.

\section{METHODS}

We collected the two box cores (11881 and 11886) during the U.K. Biogeochemical Ocean Flux Study (BOFS) program (Fig. 1). We previously reported initial ${ }^{14} \mathrm{C}$ results from these cores in Thomson et al. (1993b). The analyses were performed at SURRC by liquid scintillation counting (LSC) of benzene, which we synthesized from the $\mathrm{CO}_{2}$ released upon acid treatment of the bulk sediment $\mathrm{CaCO}_{3}$. We report here additional data for these cores, again derived by radiometric analysis, on both bulk sediment and fine $(<5 \mu \mathrm{m})$ size-fraction samples. We also present data on species-undifferentiated pelagic foraminifera fractions, hand-picked from the $>150 \mu \mathrm{m}$ size-fraction. The total sample size was a few tens of milligrams, from an initial mass of several tens of grams of wet sediment. These analyses were performed at the NSF-Arizona AMS Facility. Tables 1 and 2 list all the available data for the two cores although the plotted data and discussion are limited to the Holocene sections ( $<10 \mathrm{ka})$.

\section{RESULTS AND DISCUSSION}

The radiocarbon age/depth profile of a sediment that has accumulated at a constant rate ideally exhibits a near-constant age in a surficial bioturbated layer of $c a .10-\mathrm{cm}$ thickness (Erlenkeuser 1980; Officer 1982). Below this surface mixed layer (SML), the ${ }^{14} \mathrm{C}$ age increases linearly with depth under constant accumulation conditions. Good examples of such regular profile shapes were observed in the bulk carbonate age/depth profiles of Cores 11881 and 11886 (Thomson et al. 1993b). These two cores are both from a water depth of $4 \mathrm{~km}$, on the north and south flanks of the 


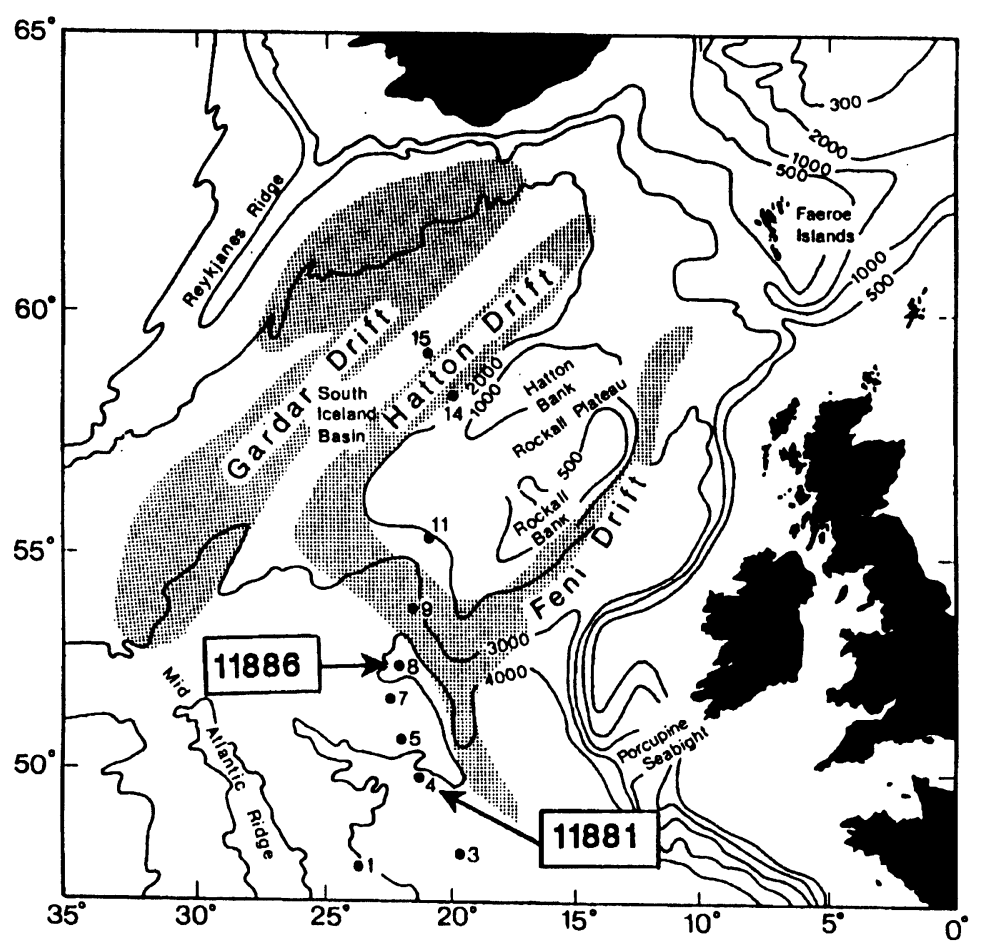

Fig. 1. Bathymetric map of the locations of 1989 Biogeochemical Ocean Flux Study (BOFS) stations from RRS Discovery Cruise 187, including those of the two cores discussed. Major sediment drifts are shown as shaded areas (after Kidd and Hill 1986).

East Thulean Rise in the northeast Atlantic (Fig. 1). Northern flank Core 11886 has accumulated almost twice as fast as southern flank Core 11881 (Thomson et al. 1993b; Figs. 2 and 3). A similar approximate doubling in accumulation flux was also observed for the supply of the short-term (100yr) tracer ${ }^{210} \mathrm{~Pb}_{\text {excess }}$ from the water column $\left(0.81 \mathrm{dpm} \mathrm{cm}{ }^{-2} \mathrm{yr}^{-1}{ }^{210} \mathrm{~Pb}_{\text {excess }}\right.$ for Core $11881 \mathrm{vs.} 1.48$ $\mathrm{dpm} \mathrm{cm}{ }^{-2} \mathrm{yr}^{-1}$ for Core 11886) (Thomson et al. 1993a). A comparison of the material fluxes in different size classes revealed that these accumulation rate differences were caused by an increased supply of the fine component $(<5 \mu \mathrm{m})$ to the site of Core 11886 relative to the site of Core 11881, presumably as a consequence of bottom-current redistribution (Thomson et al. 1993b). Both cores are carbonate-rich, and coccoliths form the bulk of both the sediment carbonate and the fine fraction. Thus, we reasoned that the ages of large foraminifera might be similar to the total carbonate ages in the more slowly accumulating Core 11881 , but slightly younger than the bulk carbonate ages in the more rapidly accumulating Core 11886 because it had experienced an augmented lateral flux of fine material. We tested this hypothesis by analyzing additional samples from mixed pelagic foraminiferal species $(150-400 \mu \mathrm{m})$. The results (Figs. 2 and 3$)$ were contrary to expectation. The foraminiferal AMS ages from the Holocene sections of both cores were consistently older than the bulk carbonate ages. In the more slowly accumulating Core 11881, the age difference was also uniformly greater $(+1.1 \mathrm{ka})$ than that of the more rapidly accumulating core $(+0.76 \mathrm{ka}$ for Core 11886$)$. In both cores, further radiometric analyses of the fine $(<5 \mu \mathrm{m})$ fractions of the same samples, obtained during size fractionation, had similar radiometric ages to those of the bulk carbonate. For both cores, remarkably similar mean accumulation rates derived from the radiometric bulk carbonate and AMS foraminifera age profiles from the Holocene (Figs. 2 and 3). 
TABLE $1 .{ }^{14} \mathrm{C}$ Age Data for NE Atlantic Core 11881

\begin{tabular}{lrrc}
\hline Lab no. & $\begin{array}{r}\text { Depth } \\
\text { (cm) }\end{array}$ & $\begin{array}{r}\text { Age } \\
(\mathrm{BP})\end{array}$ & $\begin{array}{r}\text { Uncertainty } \\
(1 \mathrm{\sigma})\end{array}$ \\
\hline Bulk Sediment & & & \\
GU-3557* & $0.0-0.5$ & 2700 & 60 \\
GU-3558 & $0.5-1.0$ & 3010 & 60 \\
GU-3559 & $1.0-1.5$ & 2830 & 70 \\
GU-3560 & $1.5-2.0$ & 3070 & 100 \\
GU-3561 & $2.0-2.5$ & 2800 & 60 \\
GU-3562 & $2.5-3.0$ & 2930 & 60 \\
GU-3563 & $3.0-3.5$ & 2690 & 60 \\
GU-3564 & $3.5-4.0$ & 2950 & 60 \\
GU-3565 & $4.0-4.5$ & 3000 & 60 \\
GU-3566 & $4.5-5.0$ & 2950 & 60 \\
GU-3567 & $5.0-5.5$ & 2970 & 60 \\
GU-3568 & $5.5-6.0$ & 3020 & 100 \\
GU-3569 & $6.0-6.5$ & 3150 & 70 \\
GU-3570 & $6.5-7.0$ & 3040 & 60 \\
GU-3571 & $7.0-7.5$ & 3340 & 60 \\
GU-3572 & $7.5-8.0$ & 3190 & 60 \\
GU-3573 & $8.0-8.5$ & 3520 & 70 \\
GU-3574 & $8.5-9.0$ & 3410 & 70 \\
GU-3575 & $9.0-9.5$ & 3550 & 60 \\
GU-3576 & $9.5-10$ & 3640 & 60 \\
GU-3577 & $10-11$ & 3680 & 60 \\
GU-3790 & $11-12$ & 3870 & 60 \\
GU-3791 & $12-13$ & 3990 & 50 \\
GU-3792 & $13-14$ & 4280 & 50 \\
GU-3793 & $14-15$ & 4810 & 50 \\
GU-3578 & $15-16$ & 5280 & 60 \\
GU-3794 & $16-17$ & 5560 & 50 \\
GU-3795 & $17-18$ & 5980 & 50 \\
GU-3796 & $18-19$ & 6240 & 50 \\
GU-3797 & $19-20$ & 6620 & 70 \\
GU-3579 & $21-22$ & 7390 & 60 \\
GU-3798 & $22-23$ & 7630 & 60 \\
GU-3799 & $23-24$ & 7970 & 60 \\
GU-3800 & $24-25$ & 8020 & 70 \\
GU-3580 & $25-26$ & 8610 & 60 \\
GU-3801 & $27-28$ & 9260 & 70 \\
GU-3581 & $30-31$ & 10,450 & 60 \\
GU-3802 & $32-33$ & 10,850 & 90 \\
GU-3582 & $35-36$ & 11,710 & 80 \\
GU-3803 & $37-38$ & 12,480 & 100 \\
GU-3583 & $40-41$ & 13,610 & 90 \\
GU-3804 & $42-43$ & 13,980 & 100 \\
GU-3584 & $45-46$ & 15,990 & 140 \\
<5 40 Fraction & & & \\
GU-3781 & $15-17$ & 5680 & 60 \\
GU-3782 & $24-26$ & 8820 & 80 \\
GU-3783 & $34-36$ & 13,160 & 260 \\
& & &
\end{tabular}


TABLE 1. Continued

\begin{tabular}{|c|c|c|c|}
\hline Lab no. & $\begin{array}{l}\text { Depth } \\
\text { (cm) }\end{array}$ & $\begin{array}{l}\text { Age } \\
\text { (BP) }\end{array}$ & $\begin{array}{l}\text { Uncertainty } \\
(1 \sigma)\end{array}$ \\
\hline \multicolumn{4}{|c|}{ Mixed Pelagic Foraminifera (>150 $\mu$ m fraction) } \\
\hline $\begin{array}{l}\text { AA-10306† } \\
\text { AA-10307 } \\
\text { AA-10308 } \\
\text { AA-10309 }\end{array}$ & $\begin{array}{l}15-17 \\
24-26 \\
34-36 \\
45-46\end{array}$ & $\begin{array}{r}6540 \\
9565 \\
11,980 \\
13,010\end{array}$ & $\begin{array}{r}70 \\
75 \\
110 \\
95\end{array}$ \\
\hline
\end{tabular}

TABLE 2. ${ }^{14} \mathrm{C}$ Age Data for NE Atlantic Core 11886

\begin{tabular}{lccc}
\hline Lab no. & $\begin{array}{c}\text { Depth } \\
(\mathrm{cm})\end{array}$ & $\begin{array}{c}\text { Age } \\
(\mathrm{BP})\end{array}$ & $\begin{array}{c}\text { Uncertainty } \\
(1 \mathrm{\sigma})\end{array}$ \\
\hline Bulk Sediment & & & \\
GU-3630 & $0.0-0.5$ & 2380 & 120 \\
GU-3631 & $2.5-3.0$ & 2200 & 60 \\
GU-3632 & $5.0-5.5$ & 2320 & 80 \\
GU-3633 & $7.5-8.0$ & 2490 & 90 \\
GU-3634 & $10-11$ & 2660 & 50 \\
GU-3635 & $15-16$ & 3460 & 50 \\
GU-3636 & $20-21$ & 3970 & 50 \\
GU-3637 & $25-26$ & 5090 & 50 \\
GU-3638 & $30-31$ & 5960 & 50 \\
GU-3639 & $35-36$ & 6930 & 60 \\
GU-3640 & $40-41$ & 7680 & 60 \\
GU-3641 & $45-46$ & 8590 & 70 \\
GU-3642 & $50-51$ & 9230 & 80 \\
$<5 \mu m$ Fraction & & \\
GU-3785 & $9-11$ & 2740 & 60 \\
GU-3786 & $19-21$ & 3930 & 50 \\
GU-3787 & $29-31$ & 5600 & 50 \\
GU-3788 & $39-41$ & 7670 & 60 \\
GU-3789 & $45-46.5$ & 8830 & 60 \\
Mixed Pelagic Foraminifera & \\
(>150 $\mu$ fraction) & & \\
AA-10310 & $9-11$ & 3320 & 65 \\
AA-10311 & $19-21$ & 4780 & 65 \\
AA-10313 & $39-41$ & 8365 & 85 \\
AA-10314 & $45-46.5$ & 9260 & 110 \\
\hline \multicolumn{4}{c}{}
\end{tabular}


Radiocarbon Age (yr BP)

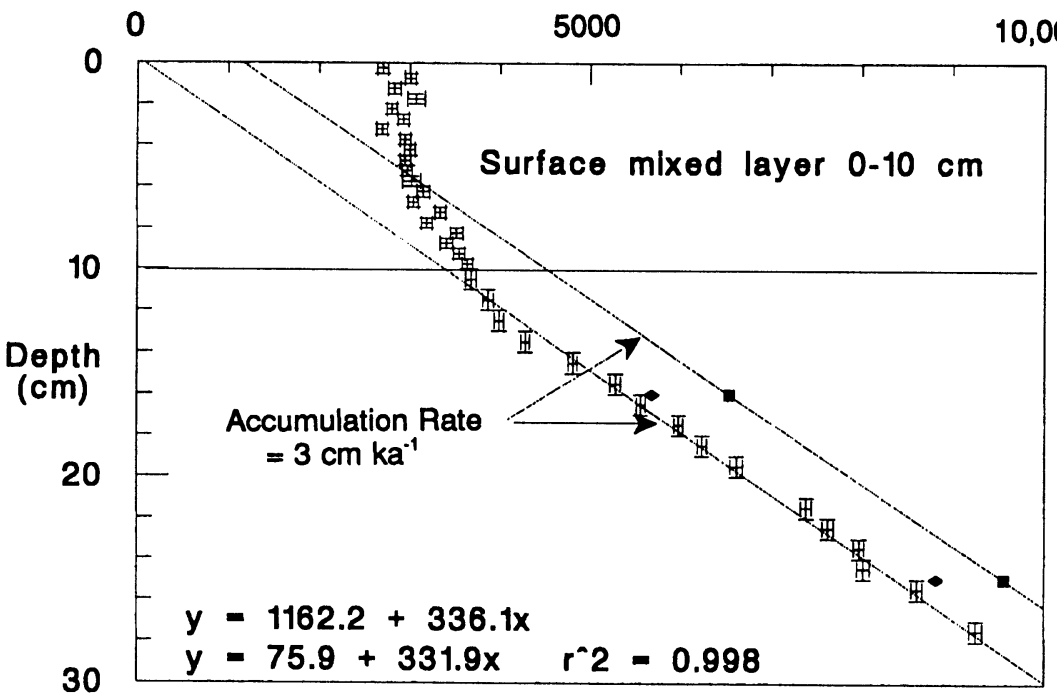

Fig. 2. Holocene bulk carbonate ${ }^{14} \mathrm{C}$ age/depth profile for Core 11881 , with AMS ages of mixed pelagic foraminifera $>150 \mu \mathrm{m}(\square)$ and radiometric ages of $<5 \mu \mathrm{m}$ size fractions $(\diamond)$ also shown. Sediment accumulation rates were calculated independently from regression analysis of bulk sample ages from $>10 \mathrm{~cm}$ depth and from the AMS data. There are only two $>150 \mu \mathrm{m}$ AMS data points for the regression line illustrated $\left(r^{2}=1.0\right)$.

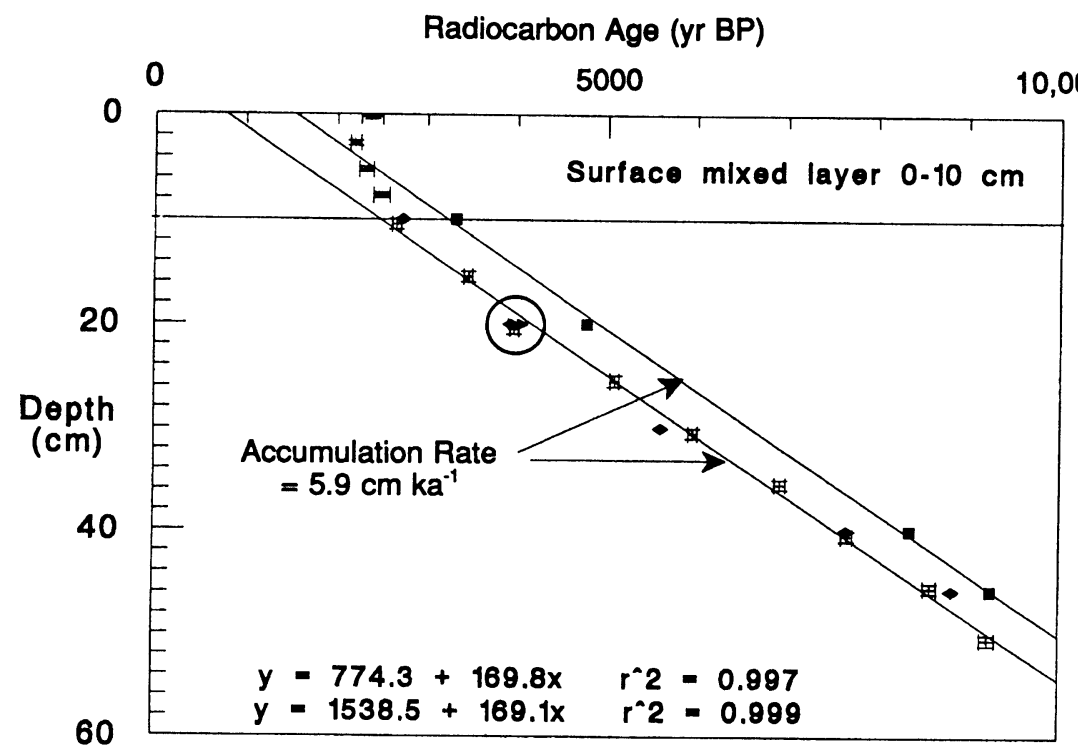

Fig. $3 .{ }^{14} \mathrm{C}$ age/depth profile for Core 11886 , symbols and regression lines are as for Fig. 2, except that the AMS and radiometric ages from a single gas from a $20-5 \mu \mathrm{m}$ size fraction are also shown $(\bullet)$. The circle contains one bulk carbonate radiometric analysis, one $<5 \mu \mathrm{m}$ size fraction radiometric analysis and both $20-5 \mu \mathrm{m}$ size fraction analyses. 
We consider several possibilities that would account for the offset between the bulk carbonate and foraminifera ages:

1. Some systematic analytical difference might exist between the SURRC $\beta$ counting and Arizona AMS methods. This is an unlikely cause of such a large effect because the analytical quality of ${ }^{14} \mathrm{C}$ laboratories is intensively intercalibrated through standard materials. Table 3 illustrates data derived from the Third International Radiocarbon Intercomparison (TIRI) for the two laboratories (A. J. T. Jull, personal communication, 1994), together with the median result of all the participating laboratories (ca. 70) (E. M. Scott, personal communication, 1994). As a further independent test, we prepared and split a single sample of $\mathrm{CO}_{2}$ gas (Core 11886, 19-21 cm, 20-5 $\mu \mathrm{m}$ size fraction). The bulk of the gas was converted to benzene and analyzed at SURRC, producing an age of $3960 \pm 100 \mathrm{BP}$. A smaller fraction was analyzed by AMS at Arizona and gave a concordant age of $4060 \pm 160 \mathrm{BP}$ (Fig. 3).

2. Vital effects are not expected in the ${ }^{14} \mathrm{C}$ ages of calcite formed by coccoliths or pelagic foraminifera from sea water and ${ }^{14} \mathrm{C}$ ages are corrected for isotopic fractionation via $\delta^{13} \mathrm{C}$ as a matter of course.

3. ${ }^{14} \mathrm{C}$ reservoir effects are not expected because at the latitudes of these cores there is a ${ }^{14} \mathrm{C}$ age difference of only $250 \mathrm{yr}$ between the surface ocean and water at $3 \mathrm{~km}$ depth (Broecker et al. 1988b). Significant differences in the surface ocean (where both the coccoliths and pelagic foraminifera grow) are therefore improbable.

4. Dissolution effects are unlikely because the water depth of the cores $(4 \mathrm{~km})$ is above the Atlantic calcite lysocline (Oxburgh and Broecker 1993). In addition, we performed the AMS analyses on the largest and best-preserved foraminiferal specimens in which we observed neither significant carbonate dissolution nor reprecipitation features.

5. Some carbon may have been added from a different source and of a different age to one of the fractions. Most obviously, this could be carbonate added to the fine fraction from terrigenous sources or nearby winnowing of the seabed. In either case, we would expect the fine carbonate to be older than the foraminifera, but we found the opposite and discounted this possibility.

TABLE 3. Comparison of TIRI results between SURRC by beta counting and the University of Arizona by AMS. Results are in conventional ${ }^{14} \mathrm{C}$ yr BP.

\begin{tabular}{lrrr}
\hline Sample & \multicolumn{1}{c}{ Arizona } & \multicolumn{1}{c}{ SURRC } & $\begin{array}{c}\text { Median of } \\
\text { all labs }\end{array}$ \\
\hline B & $4475 \pm 55$ & $4540 \pm 50$ & 4500 \\
D & $3890 \pm 80$ & $3830 \pm 50$ & 3800 \\
E & $11,265 \pm 70$ & $11,120 \pm 60$ & 11,090 \\
\hline
\end{tabular}

If the above possibilities are all unlikely, then the remaining contender is that the age offset is produced by size-related differential bioturbation in the SML. For this explanation to hold true, the burial of the large foraminifera must be delayed in some fashion during their passage through the SML, relative to the bulk of the sediment which is finer. The large foraminifera selected for AMS analysis compose, at most, a few percent of the total sediment. As explained above, it may be that they are processed differently by the sediment infauna that perform the bioturbative mixing. The data and arguments of Wheatcroft (1992) show that entirely different bioturbation intensities apply to the large foraminifera compared with the bulk finer sediments. The biological diffusivity of the fine $(<16 \mu \mathrm{m})$ fraction is $>1 \mathrm{~cm}^{2} \mathrm{yr}^{-1}$, whereas that for sand-sized particles is $<0.1 \mathrm{~cm}^{2} \mathrm{yr}^{-1}$. Large $(>150 \mu \mathrm{m})$ foraminifera have also been shown to be less deeply worked down into a recent turbidite 
surface than natural radionuclides, in a case where both the foraminifera and radionuclides have been deposited since emplacement $1 \mathrm{ka}$ ago (Thomson, Colley and Weaver 1988; Thomson and Weaver 1994). One residual uncertainty in this bioturbation interpretation, however, is the significance of the magnitude of the different age offsets of the two cores. If it is produced purely as a consequence of bioturbation, the larger age offsets in Core 11881 would be expected to be a consequence of a longer residence time in the sediment SML caused by a slower accumulation rate. Residence times may be estimated by dividing the SML depths of the cores by their accumulation rates, which gives 3.0 and $1.6 \mathrm{ka}$ for Cores 11881 and 11886, respectively (Thomson et al. 1993b). On the other hand, modeling the whole core ${ }^{14} \mathrm{C}$ data by the Erlenkeuser (1980) method yields ages for freshly deposited material in the two cores of 0.56 and $0.95 \mathrm{ka}$, for Cores 11881 and 11886 respectively (Thomson et al. 1993b). This difference of $0.39 \mathrm{ka}$ is similar to the mean difference in the offsets in the two cores, $(1.1-0.76=0.34 \mathrm{ka})$. The possibility remains, therefore, that the age offset produced by bioturbation is, in fact, similar in the two cores, but that the bulk carbonate age against which it is developed is $0.39 \mathrm{ka}$ older in Core 11886 than in Core 11881. This latter explanation would be consistent with a longer transit time for the increased, laterally transported fine component of Core 11886 . Both cores accumulate at somewhat greater rates than the Atlantic average, which is generally taken as $c a .2 .5 \mathrm{~cm} \mathrm{ka}^{-1}$ (Balsam and McCoy 1987). Further work is needed to ascertain whether the age offset generally increases as sediment accumulation rate decreases, as would be expected from the differential bioturbation interpretation.

Total bulk ${ }^{14} \mathrm{C}$ analyses of the SML of Core 11881 (Fig. 4) suggest that the mixing process in the SML is likely to be complex. The detailed data from the upper $10 \mathrm{~cm}$ of Core 11881 reveal a well-mixed region from $0-5 \mathrm{~cm}$ overlying a less-well-mixed region from 5-10 cm, rather than a single SML. The possibility that different effective surface mixed layer depths and mixing intensities apply to different size fractions should also be investigated in future work.

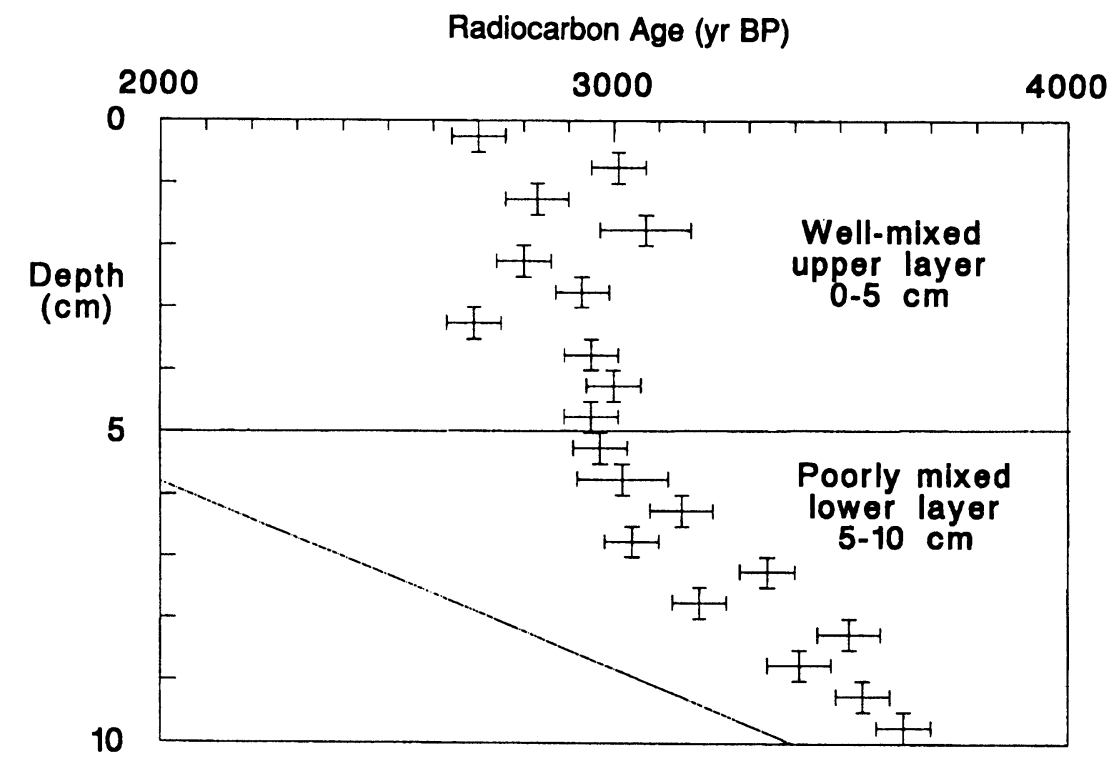

Fig. 4. Detail of bulk carbonate ${ }^{14} \mathrm{C}$ age/depth profile in the SML $(0-10 \mathrm{~cm})$ of Core 11881. The diagonal line is the regression line of ${ }^{14} \mathrm{C}$ age on depth from which the accumulation rate was calculated (Fig. 2). 
Only a limited amount of work on this theme has been undertaken, despite the fact that carbonate sediments similar to those investigated here floor most of the deep Atlantic and form an important paleoenvironmental record. Jones et al. (1989) and Paull et al. (1991) also found that +1 to $+2 \mathrm{ka}$ age offsets in large foraminifera are the norm rather than the exception in Holocene sediments. Their work concerned longer cores encompassing longer intervals where accumulation was not steady-state, and variable offsets were obtained. The $\delta^{18} \mathrm{O}, \delta^{13} \mathrm{C}$ and $\mathrm{Cd} / \mathrm{Ca}$ techniques, which provide the most important deep-sea records for paleoclimatic and paleoceanographic studies, are all based on analysis of large foraminifera shells similar to those utilized here. Although such shells form a small proportion of the sediment, their importance for paleoceanographic applications is out of all proportion to their low abundance. The findings here have a direct relevance to such techniques used to investigate the deep-sea sediment record, and suggest that the bulk of the sediment is offset toward younger ages by comparison with the records derived from foraminifera. This has already been demonstrated by Paull et al. (1991) for the oxygen isotope record. Other techniques based on finer sedimentary components, such as palynology (e.g., Rossignol-Strick and Planchais 1989) or the $\mathrm{U}_{\mathrm{K}}^{37}$ paleotemperature method, based on coccolith metabolites (e.g., Eglinton et al. 1992), may therefore also refer to a younger period than the corresponding records obtained from foraminifera at the same depths in the same cores. On the available evidence, this effect is likely to be particularly marked in slowly accumulated, rather than rapidly accumulated cores.

\section{ConClusion}

${ }^{14} \mathrm{C}$ ages of the relatively rare, large foraminifera are older than either the bulk sediment or fine $(<5$ $\mu \mathrm{m}$ ) carbonate coexisting at the same depth in the sediment, by +0.76 and $+1.1 \mathrm{ka}$ in two cores with different accumulation rates. Nevertheless, the offsets in the two cores are so consistent that almost identical sediment accumulation rates are calculated from both the foraminifera and bulk sediment age/depth profiles in both cores. The only explanation for age differences of this magnitude appears to be differential mixing of different-sized particles in the SML, although there is a residual uncertainty as to whether the magnitudes of the offset in these two cores are produced purely by bioturbation. This is because the model-calculated ages of freshly deposited bulk material are different in the two cores under study by an amount similar to the foraminifera/bulk age offset difference. The fact that a comparison of the sedimentation rates derived from pelagic foraminifera and bulk carbonate within each core are almost identical would suggest that the same mixing intensities have operated throughout the Holocene in both cores.

Paleoceanographic records are generally based on changes in some parameter over time, measured in a particular sediment size fraction or sediment component. Our research indicates that all such records cannot be assumed to be contemporaneous merely because they derive from the same depths in the sediments.

\section{ACKNOWLEDGMENTS}

This work was supported by NERC Special Topic grant GST/2/302, and the AMS analyses, carried out at the NSF-Arizona Facility, were funded by NERC Scientific Services allocation RCL-SC 479/ 1291. We also acknowledge permission granted to us to publish the NSF-Arizona AMS results for the TIRI Project. BOFS contribution 256; IOSDL contribution 95017. 


\section{REFERENCES}

Aller, R. C. and DeMaster, D. J. 1984 Estimates of particle flux and reworking at the deep-sea floor using ${ }^{234} \mathrm{Th} /{ }^{38} \mathrm{U}$ disequilibrium. Earth and Planetary Science Letters 67: 308-318.

Balsam, W. L. and McCoy, F. W. Jr. 1987 Atlantic sediments: Glacial/interglacial comparisons. Paleoceanography 2: 531-542.

Bard, E., Arnold, M., Duprat, J., Moyes, J. and Duplessy, J.-C. 1987 Reconstruction of the last deglaciation: Deconvolved records of $\delta^{18} \mathrm{O}$ profiles, micropalaeontological variations and mass spectrometric ${ }^{14} \mathrm{C}$ dating. Climate Dynamics 1: 101-112.

Boudreau, B. P. 1986a Mathematics of tracer mixing in sediments: 1 . Spatially dependent, diffusive mixing. American Journal of Science 286: 161-198.

1986b Mathematics of tracer mixing in sediments: 2. Non-local mixing and biological conveyor belt phenomena. American Journal of Science 286: 199-238.

Broecker, W. S., Andrée, M., Wölfli, W., Oeschger, H., Bonani, G. Kennett, J. and Peteet, D. 1988a The chronology of the last deglaciation: Implications to the cause of the Younger Dryas event. Paleoceanography 3: 1-19.

Broecker, W. S., Andrée, M., Bonani, G., Wölfli, W., Oeschger, H., Klas, M., Mix, A. and Curry, W. 1988b Preliminary estimates for the radiocarbon age of deep water in the glacial ocean. Paleoceanography 3: 659670.

Cochran, J. K. 1985 Particle mixing rates in sediments of the eastern equatorial Pacific: Evidence from ${ }^{210} \mathrm{~Pb}$, ${ }^{239,240} \mathrm{Pu}$ and ${ }^{137} \mathrm{Cs}$ distributions at MANOP sites. Geochimica et Cosmochimica Acta 49: 1195-1210.

DeMaster, D. J. and Cochran, J. K. 1982 Particle mixing rates in deep-sea sediments determined from excess ${ }^{210} \mathrm{~Pb}$ and ${ }^{32} \mathrm{Si}$ profiles. Earth and Planetary Science Letters 61: 257-281.

Duplessy, J.-C., Arnold, M., Maurice, P., Bard. E., Duprat, J. and Moyes, J. 1986 Direct dating of the oxygen-isotope record of the last deglaciation by ${ }^{14} \mathrm{C}$ accelerator mass spectrometry. Nature 320: 350-352.

Eglinton, G., Bradshaw, S. A., Rosell, A., Sarnthein, M., Pflaumann, U. and Tiedemann, R. 1992 Molecular record of secular sea surface temperature changes on 100-year timescales for glacial terminations I, II and IV. Nature 356: 423-426.

Erlenkeuser, H. $1980{ }^{14} \mathrm{C}$ age and vertical mixing of deep-sea sediments. Earth and Planetary Science Letters 47: 319-326.

Jansen, E. and Veum, T. 1990 Evidence for two-step deglaciation and its impact on North Atlantic deep-water circulation. Nature 343: 612-616.

Jones, G. A., Jull, A. J. T., Linick, T. W. and Donahue, D. J. 1989 Radiocarbon dating of deep-sea sediments: A comparison of accelerator mass spectrometer and beta-decay methods. Radiocarbon 31(2): 105-116.

Kidd, R. B. and Hill, P. R. 1986 Sedimentation on mid- ocean sediment drifts. In Summerhayes, C. P. and Shackleton, N. J., eds., North Atlantic Palaeoceanography. Geological Society of London Special Publication 21: 87-102.

McCave, I. N. 1988 Biological pumping upwards of the coarse fraction of deep-sea sediments. Journal of Sedimentary Petrology 58: 148-158.

Nozaki, Y., Cochran, J. K., Turekian, K. K. and Keller, G. 1977 Radiocarbon and ${ }^{210} \mathrm{~Pb}$ distribution in submersible-taken deep-sea cores from Project FAMOUS. Earth and Planetary Science Letters 34: 167-173.

Officer, C. B. 1982 Mixing, sedimentation rates and age dating for sediment cores. Marine Geology 46: 261278.

Oxburgh, R. and Broecker, W. S. 1993 Pacific carbonate dissolution revisited. Palaeogeography, Palaeoclimatology, Palaeoecology 103: 31-39.

Paull, C. K., Hills, S. J., Thierstein, H. R., Bonani, G. and Wölfli, W. $1991{ }^{14} \mathrm{C}$ offsets and apparently non-synchronous $\delta^{18} \mathrm{O}$ stratigraphies between nannofossil and foraminiferal carbonates. Quaternary Research 35: 274-290.

Rossignol-Strick, M. and Planchais, N. 1989 Climate patterns revealed by pollen and oxygen isotope records of a Tyrrhenian Sea core. Nature 342: 413416.

Ruddiman, W. F., Jones, G. A., Peng, T.-H, Glover, L. K., Glass, B. P. and Liebertz, P. J. 1980 Tests for size and shape dependency in deep-sea mixing. Sedimentary Geology 25: 257-276.

Sanderson, B. 1985 How bioturbation supports manganese nodules at the sediment-water interface. Deep-Sea Research 32: 1281-1285.

Schiffelbein, P. 1984 Effect of benthic mixing on the information content of deep-sea stratigraphical signals. Nature 311: 651-653.

1985 Extracting the benthic mixing impulse response function: A constrained deconvolution technique. Marine Geology 64: 313-336.

Smith, C. R. 1992 Factors controlling bioturbation in deep-sea sediments and their relation to models of carbon diagenesis. In Rowe, G. T. and Pariente, V., eds., Deep-Sea Food Chains and the Global Carbon Cycle. Dordrecht Kluwer Academic Publishers: 375-393.

Smith, C. R., Pope, R. H., DeMaster, D. J. and Magaard, L. 1993 Age-dependent mixing of deep-sea sediments. Geochimica et Cosmochimica Acta 57: 14731488.

Smith, J. N., Boudreau, B. P., Schafer, C. T. and Noshkin, V. 1986 Plutonium and ${ }^{210} \mathrm{~Pb}$ distributions in Northeast Atlantic sediments: Subsurface anomalies caused by non-local mixing. Earth and Planetary Science Letters 81: 15-28.

Thomson, J., Colley, S., Anderson, R., Cook, G. T. and MacKenzie, A. B. ${ }^{1993 a}{ }^{210} \mathrm{~Pb}$ in the sediments and water column of the Northeast Atlantic from 47 to 
$59^{\circ} \mathrm{N}$ along $20^{\circ} \mathrm{W}$. Earth and Planetary Science Letters 115: 75-87.

Thomson, J., Colley, S., Anderson, R., Cook, G. T., MacKenzie, A. B. and Harkness. D. D. 1993b Holocene sediment fluxes in the northeast Atlantic from ${ }^{230} \mathrm{Th}_{\text {excess }}$ and radiocarbon measurements. Paleoceanography 8: 631-650.

Thomson, J., Colley, S. and Weaver, P. P. E. 1988 Bioturbation into a recently emplaced deep-sea turbidite as revealed by ${ }^{210} \mathrm{~Pb}_{\text {excess, }}{ }^{230} \mathrm{Th}_{\text {excess }}$ and planktonic foraminifera distributions. Earth and Planetary Science Letters 90: 157-173.

Thomson, J. and Weaver, P. P. E. 1994 An AMS radiocar- bon method to determine the emplacement time of recent deep-sea turbidites. Sedimentary Geology 89: 1-7.

Wheatcroft, R. A. 1992 Experimental tests for particle size-dependent bioturbation in the deep ocean. Limnology and Oceanography 37: 90-104.

Wheatcroft, R. A. and Jumars, P. A. 1987 Statistical re-analysis for size dependency in deep-sea mixing. Marine Geology 77: 157-163.

Wheatcroft, R. A., Jumars, P. A., Smith, C. R. and Nowell, A. R. M. 1990 A mechanistic view of the particulate biodiffusion coefficient: Step lengths, rest periods and transport directions. Journal of Marine Research 48: 177-207. 